\title{
The isotopic record at an alpine glacier and its implications for local climatic changes and isotopic homogenization processes
}

\author{
He Yuanoing, ${ }^{1}$ Wilfred H. Theakstone, ${ }^{2}$ Yao Tandong, ${ }^{1}$ Shi Yafeng ${ }^{1}$ \\ ${ }^{1}$ Laboratory of Ice Core and Cold Regions Environment, Cold and Arid Regions Environmental and Engineering Research Institute, \\ Chinese Academy of Sciences, Lanzhou 730000, Gansu, China \\ ${ }^{2}$ Department of Geography, University of Manchester, Manchester M13 9PL, England
}

\begin{abstract}
Stratigraphic variations of oxygen isotopes in the snow which accumulates during the winter at the Norwegian glacier Austre Okstindbreen are not entirely eliminated after 1-2 months of ablation in the following summer. The relationship between regional temperature changes and $\delta^{18} \mathrm{O}$ values in the snowpack is affected by many natural factors, but 1989/90 winter air temperatures were reflected in the snow which remained on Austre Okstindbreen at $1350 \mathrm{~m}$ a.s.l. in July 1990. There were many variations of $\delta^{18} \mathrm{O}$ values in the $4.1 \mathrm{~m}$ of snow above the 1989 summer surface, but variations in the underlying firn were relatively small. Meltwater percolation modifies the initial variations of $\delta^{18} \mathrm{O}$ values in the snowpack. At a site below the mean equilibrium-line altitude on Austre Okstindbreen, increased isotopic homogenization within a 10 day period in July accompanied an increase of the mean $\delta^{18} \mathrm{O}$ value. Although the isotopic record at a temperate glacier is likely to be influenced by more factors than is that at polar glaciers, it can provide an estimate of the approximate trend of local temperature variations.
\end{abstract}

\section{INTRODUCTION}

For some four decades, seasonal changes of the isotopic composition of deposited snow at polar ice caps have been used to date glacier ice and to determine past climatic conditions. In contrast, there have been few reports about the isotopic composition of snow at alpine temperate glaciers in relation to climatic conditions, principally because of the effects of meltwater percolation on the isotopic stratigraphy (Oeschger and others, 1978; Tangborn, 1980; Oerter and others, 1985; Wang, 1985; Wagenbach, 1989; Naftz and others, 1993; Raben and Theakstone, 1994, 1997). Here, we discuss observations made at Austre Okstindbreen $\left(66^{\circ} 00^{\prime} \mathrm{N}, 14^{\circ} 16^{\prime} \mathrm{E}\right)$, the largest glacier of the Okstindan area, Norway, which covers about $14 \mathrm{~km}^{2}$ at $1700-730 \mathrm{~m}$ a.s.l. (Fig. 1). The mean equilibrium-line altitude (ELA) is about $1250 \mathrm{~m}$.

Studies of snowpack chemistry at Austre Okstindbreen have been reported by He and Theakstone (1994) and Raben and Theakstone (1998). In July 1990, samples of snow and firn were collected at the glacier in an attempt to elucidate problems concerning (l) isotopic variations during snow accumulation on an alpine temperate glacier, and their relations to changes of local climatic conditions, (2) the influence of meltwater percolation on the isotopic composition of snow at different altitudes, and (3) processes of homogenization of the isotopic composition of melting snow and firn. The investigations reported here were made at two sites, one above and one below the equilibrium line (Fig. 1), as part of a programme in which the isotopic composition of snow and firn in different zones was related to climatic conditions (He, 1993). Samples were analyzed at the Geophysical Isotope Laboratory of the University of Copenhagen, Denmark.

\section{THE SAMPLING PROGRAMME}

Snow accumulation at Austre Okstindbreen during winter 1989/90 was above the normal value: on 5 May 1990, the water-equivalent depth at site 90.1 (1350 m a.s.l.; Fig. 1) was $3.3 \mathrm{~m}$ (Knudsen, 1991). On 20 July, a pit $1.8 \mathrm{~m}$ deep was excav-

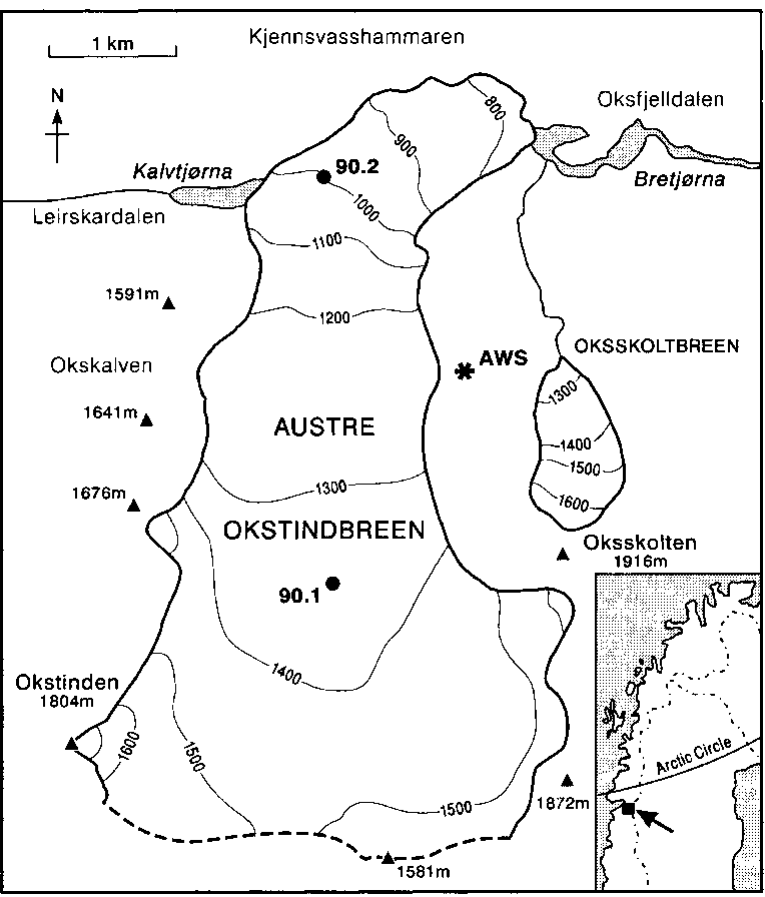

Fig. 1. The glacier Austre Okstindbreen, with the two sampling sites and the location of the automatic weather station at 1350 m. Contours are in metres. 
ated at the site; the water-equivalent thickness of the snowpack to the base of the pit was $1.0 \mathrm{~m}$. A core $4.7 \mathrm{~m}$ deep was taken from the base of the pit to the underlying glacier ice. Density measurements were not made on all core increments, but the overall thickness of the residual 1989/90 winter snowpack was estimated as $2.3 \mathrm{~m}$ w.e. The 1989 summer surface was identified at a below-surface depth of $4.1 \mathrm{~m}$, where there was a marked change of snow structure; its location was confirmed by extensive snow-depth sounding undertaken as part of the annual mass-balance programme at the glacier (Knudsen, 1991). Sixty-five samples, each $0.1 \mathrm{~m}$ long, were collected from the pit wall and core. The $6.5 \mathrm{~m}$ deep profile (Fig. 2) provided a significant dataset from the glacier's accumulation area, as it included continuous and detailed data from at least two balance years, 1988/89 and 1989/90.

The isotopic composition of the material at site 90.1 changed at the level of the 1989 summer surface. Above it, there were many variations of $\delta^{18} \mathrm{O}$ values in the snow (Fig. 2 ). In contrast, the amplitude of $\delta^{18} \mathrm{O}$ fluctuations in the underlying firn was relatively small. There was an abrupt increase of $\delta^{18} \mathrm{O}$ values at the level of the 1989 summer surface, and the upper part of the firn, between $4.1 \mathrm{~m}$ and $5.5 \mathrm{~m}$, was characterized by a progressive downward enrichment in the heavy isotope. Isotopic homogenization was particularly evident in the lowest metre of the core, from $5.5 \mathrm{~m}$ to $6.5 \mathrm{~m}$. This part of the firn was harder and denser than the overlying material, and the isotopic shift at $5.5 \mathrm{~m}$ suggests that it may have formed in an earlier period, possibly in the 1987/88 winter. The mean $\delta^{18} \mathrm{O}$ value of the 1989/90 winter snow was $-11.67 \%$, and that of the underlying firn was $-10.96 \%$.

Site 90.2 was at $1000 \mathrm{~m}$ a.s.l. (Fig. 1). A pit $1.89 \mathrm{~m}$ deep was excavated to glacier ice on 16 July; 37 samples were collected from the pit wall. The lowest sample was $0.09 \mathrm{~m}$ long; the others were $0.05 \mathrm{~m}$ long. Variations of $\delta^{18} \mathrm{O}$ values were larger in the uppermost $1.15 \mathrm{~m}$ of the snowpack than at greater depth (Fig. 3a). Ten days later, a second set of samples was collected. The thickness of the snowpack had decreased by $0.83 \mathrm{~m}$, principally as a result of melting, although some compaction may have occurred. Ten of the

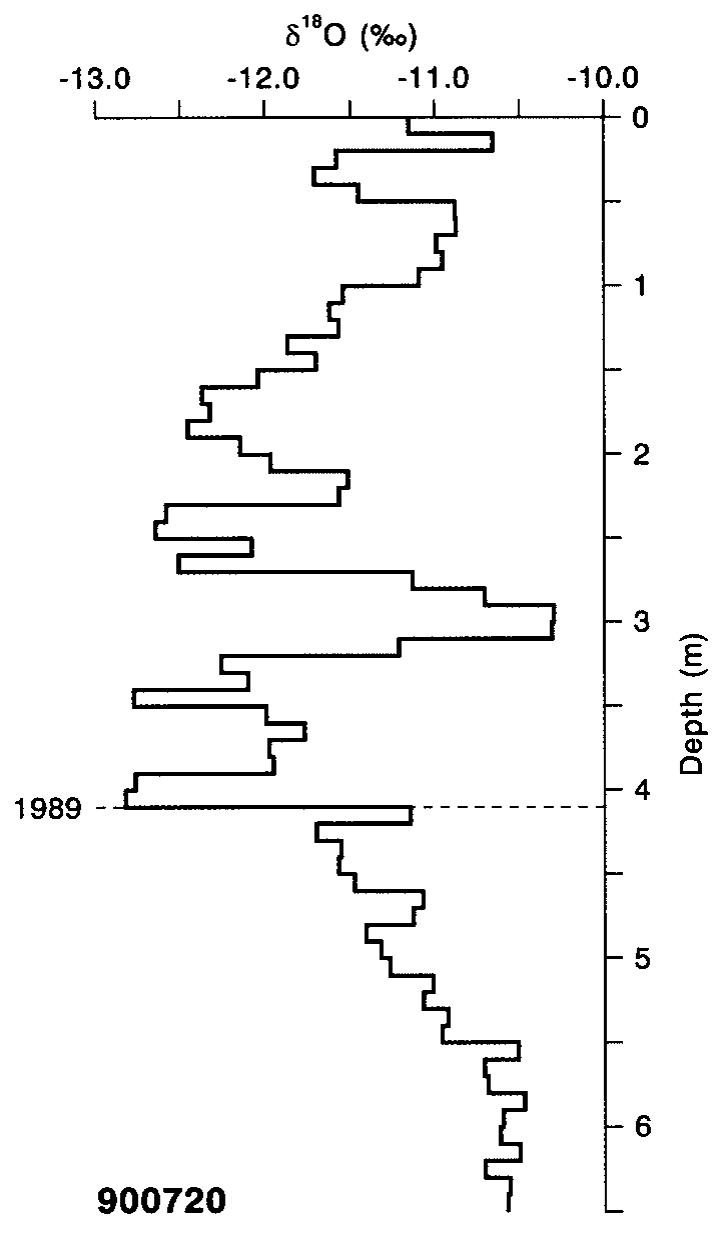

Fig. 2. Stratigraphic variations of $\delta^{18} \mathrm{O}$ values at site 90.1, Austre Okstindbreen, 20 July 1990. The 1989 summer surface was at a depth of $4.1 \mathrm{~m}$.

eleven samples collected on 26 July were $0.10 \mathrm{~m}$ long; the other sample was $0.06 \mathrm{~m}$ long (Fig. 3c). In order to facilitate comparison of the stratigraphic variations on the two dates, average $\delta^{18} \mathrm{O}$ values were calculated for $0.10 \mathrm{~m}$ increments on 16 July (Fig. 3b).
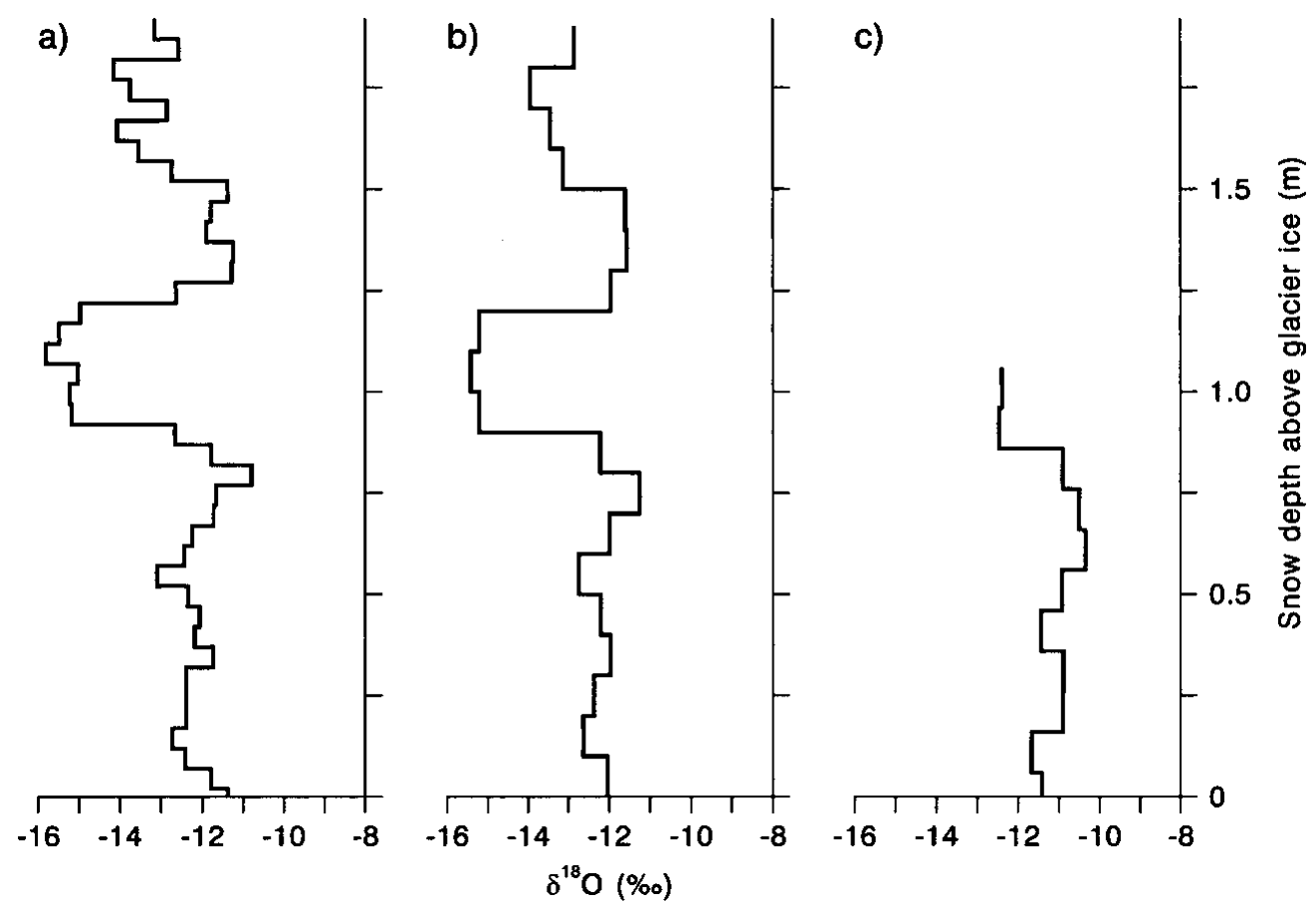

Fig. 3. Stratigraphic variations of $\delta^{18} \mathrm{O}$ values at site 90.2, Austre Okstindbreen. (a) $0.05 \mathrm{~m}$ samples, 16 fuly 1990. (b) $0.10 \mathrm{~m}$ increments formed by amalgamating pairs of $0.05 \mathrm{~m}$ samples, 16 July 1990. (c) $0.10 \mathrm{~m}$ samples, 26 fuly 1990. 


\section{THE GLIMATE OF THE OKSTINDAN AREA}

The air masses from which precipitation falls at Okstindan normally are controlled by the positions of the Azores high and the Iceland low (Ratcliffe, 1990; He, 1993; He and Theakstone, 1994). Precipitation is high when (a) low pressure is centred in the Denmark Strait, between Greenland and Iceland, (b) pressure is high over the western part of Europe and (c) air masses arrive at Okstindan from the southwest, after a very short trajectory from the ocean (Raben and others, 2000). Precipitation is monitored on a daily basis at Heggmo (399 ma.s.l.), about $10 \mathrm{~km}$ south of Austre Okstindbreen; Tustervatn (439 m a.s.l.), some $25 \mathrm{~km}$ southwest of the glacier; Mo i Rana (30 m a.s.l.), about $35 \mathrm{~km}$ to the north; and Susendal (265 $\mathrm{m}$ a.s.l.), $70 \mathrm{~km}$ to the south. The proportions of the total October 1989-May 1990 precipitation which fell in each month at the four stations were broadly similar (Table 1). Accordingly, the isotopic data from Austre Okstindbreen are compared here with precipitation data from Heggmo, the nearest station.

An automatic weather station was operating close to the western margin of Austre Okstindbreen, at $1350 \mathrm{~m}$ a.s.l., from 1 October 1988 to 31 May 1989. Mean daily temperatures there displayed good correlations with data for the same period (243 values) from Susendal $\left(r^{2}=0.72\right)$. Here, temperature data from Susendal are used in the study of the isotopic data from Austre Okstindbreen. Mean daily temperatures at Susendal for those days on which precipitation was recorded at Heggmo during the 1989/90 winter were used to calculate the mean temperatures $\left(T_{\text {mo }}\right)$ associated with successive increments of precipitation $\left(P_{\mathrm{mo}}\right)$.

\section{ISOTOPIC VARIATIONS IN THE SNOWPACK AND LOGAL GLIMATE VARIATIONS}

The $\delta^{18} \mathrm{O}$ values of precipitation during a particular event depend on the history of the air mass involved. They reflect the temperature of condensation, and, as little isotopic exchange occurs between falling snow and atmospheric moisture, they are related to in-cloud conditions. A precise relationship therefore cannot be expected between the isotopic composition of snow accumulating at Austre Okstindbreen and the air temperature measured at a distant station. In the absence of high-elevation temperature data, however, the latter may be useful in examining the general nature of isotopic variations in snow.

Vertical differences of $\delta^{18} \mathrm{O}$ values in the snow-firn profile are influenced by temporal variations of air temperature

Table 1. Monthly precipitation at four stations as a percentage of the total for the period 1 October-31 May

\begin{tabular}{lrrrr}
\hline & Susendal & Mo i Rana & Heggmo & Tustervatn \\
\hline October 1989 & 11.4 & 13.1 & 14.4 & 13.3 \\
November 1989 & 6.1 & 8.1 & 9.2 & 7.9 \\
December 1989 & 17.5 & 18.5 & 16.0 & 17.4 \\
January 1990 & 10.0 & 10.0 & 10.4 & 11.8 \\
February 1990 & 26.9 & 16.9 & 19.3 & 20.3 \\
March 1990 & 17.5 & 17.6 & 18.1 & 20.3 \\
April 1990 & 7.6 & 12.7 & 9.6 & 7.0 \\
May 1990 & 3.0 & 3.2 & 3.1 & 2.0 \\
Total (mm) & 1036.8 & 1363.3 & 1539.7 & 1259.0 \\
& & & & \\
\hline
\end{tabular}

during precipitation, and subsequently by percolating meltwater and the tendency towards isotopic homogenization. At site 90.2 , where the snow thickness decreased by $>0.8 \mathrm{~m}$ in the 10 days between collection of the two sets of samples, melting and percolation were accompanied by isotopic homogenization of the residual pack (Fig. 3). The maximum and minimum $\delta^{18} \mathrm{O}$ values were $-10.79 \%$ and $-15.84 \%$ on 16 July (Fig. $3 \mathrm{a}$ ) and $-10.34 \%$ and $-12.46 \%$ on 26 July (Fig. 3 c). The decreased variability of $\delta^{18} \mathrm{O}$ values was accompanied by an increase of the mean, from $-12.80 \%$ on 16 July to $-11.25 \%$ on 26 July. However, a comparison of the average $\delta^{18} \mathrm{O}$ values calculated for $10 \mathrm{~cm}$ increments on 16 July and the values for $10 \mathrm{~cm}$ samples on 26 July (Fig. 3b and c) indicates that the processes associated with percolation and homogenization did not eliminate all the original vertical variations of $\delta^{18} \mathrm{O}$ values.

Some changes of the initial isotope stratigraphy at site 90.1 must have been caused by meltwater percolation before samples were collected on 20 July 1990, when the snowpack was at the melting-point temperature. The liquid-water content was $2-3 \%$ to a depth of $1.5 \mathrm{~m}$; below that, to the base of the $1.8 \mathrm{~m}$ pit, the liquid-water content was around $1 \%$. Climatic data from Mo i Rana, Susendal, Heggmo and Tustervatn suggest that net accumulation of snow at $1350 \mathrm{~m}$ (site 90.1) probably did not begin before the third week of October. Using the mean daily temperature at Susendal and a lapse rate of $0.6^{\circ} \mathrm{C}$ per $100 \mathrm{~m}$, the onset of winter was calculated to have been on 23 October. Net accumulation of snow at the site probably ceased in late May. Surface melting in June and July is likely to have removed most of the snow which accumulated during the last part of the winter: the thickness of the pack decreased by $1.0 \mathrm{~m}$ w.e. between 5 May and 20 July 1990. Although meltwater percolation must have affected the $\delta^{18} \mathrm{O}$ values in the residual pack, striking variations remained on 20 July, and these probably reflect temperature variations during the accumulation season.

\section{INFERRED CONDITIONS DURING SNOW ACGUMULATION AT SITE 90.1}

The total precipitation recorded at Heggmo between 23 October 1989 and 31 May 1990 was $1417.6 \mathrm{~mm}$. The highest daily total was $93.2 \mathrm{~mm}$ (3 December), and $>40 \mathrm{~mm}$ fell on two other days (23 and 24 February). In order to facilitate comparison with the snow samples collected at site 90.2 in July, the total precipitation was divided into increments of similar size (about $40 \mathrm{~mm}$ ). Most of the increments accumulated in periods of 1-5 days, but the dry weather of May 1990 meant that the last periods were longer. Trends of mean temperature $\left(T_{\mathrm{mo}}\right)$ associated with each precipitation increment/ period $\left(P_{\mathrm{mo}}\right)$ were determined from the mean daily temperatures recorded at Susendal. The relation between $T_{\text {mo }}$ and $P_{\text {mo }}$ is plotted in Figure 4, together with the isotopic profile.

$133.7 \mathrm{~mm}$ of precipitation fell at Heggmo in the first 3 days of December 1989. This was associated with relatively high air temperatures, which were reflected by the $\delta^{18} \mathrm{O}$ values in the site 90.1 snowpack at about $1 \mathrm{~m}$ above the 1989 summer surface (Fig. 4). Temperatures were low in mid-January, but then tended to increase generally until late February, a trend reflected in the $\delta^{18} \mathrm{O}$ values about 2.3-3.6 $\mathrm{m}$ above the 1989 datum. By 20 July, the snow which had accumulated in the last part of the winter had been removed by surface melting, and the isotopic variations associated with precipitation in 


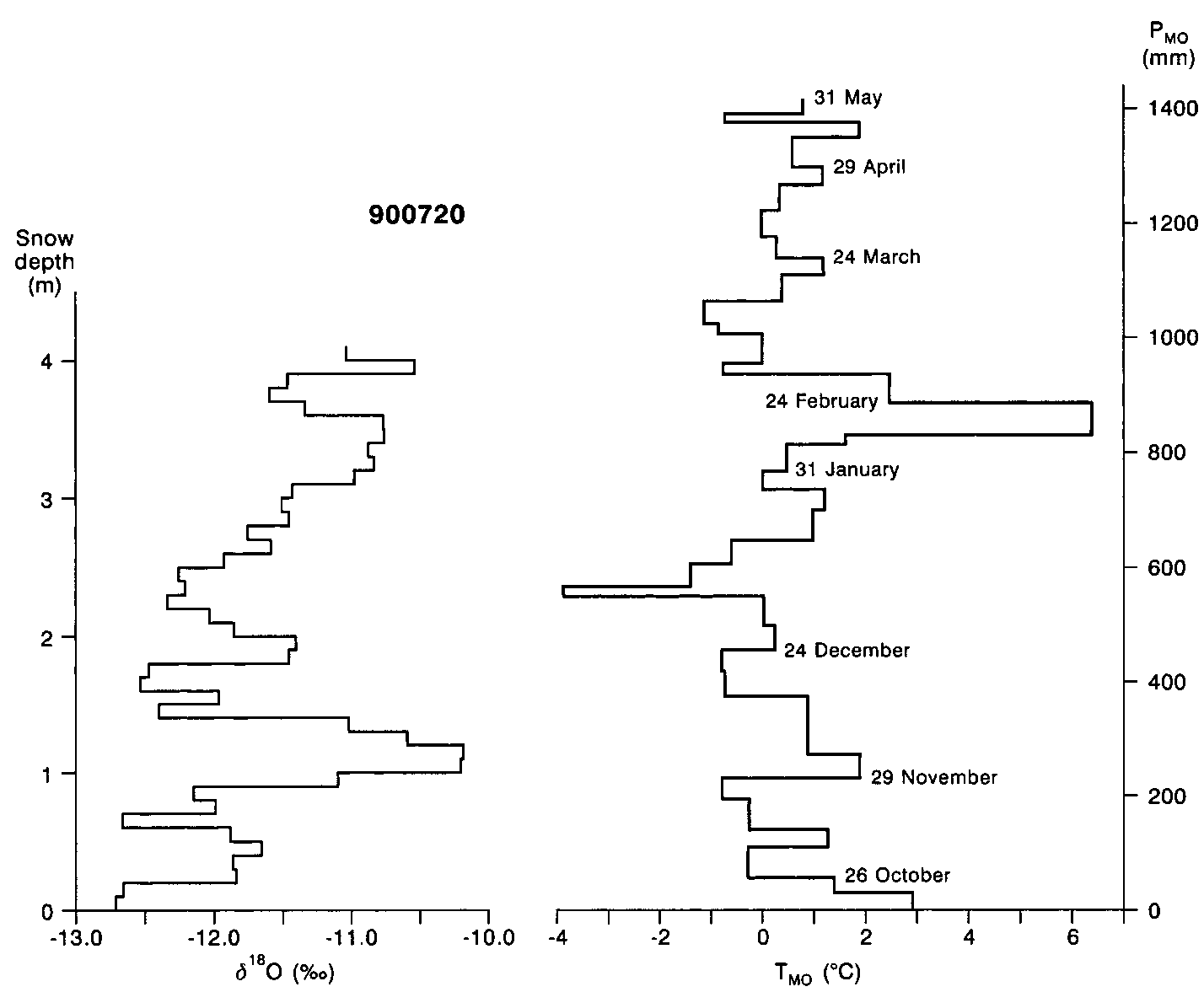

Fig. 4. Variations of air temperature at Susendal $\left(T_{\mathrm{mo}}\right)$ during periods of precipitation at Heggmo ( $\left.P_{\text {mo }}\right)$, October 1989-May 1990 (right), and the isotopic composition of the residual 1989/90 winter snowpack at site 90.1, 20 fuly 1990 (left).

March, April and May therefore were no longer present in the pack.

Variations of $\delta^{18} \mathrm{O}$ values in the lowest part of the site 90.1 snowpack at $1350 \mathrm{~m}$ in July did not reflect the variations of early winter temperatures. In part, this may have been a result of the more complex climatic situation of October and November, shown by the mean monthly meteorological charts (Ratcliffe, 1990). It also is possible that downward percolation of meltwater was hindered by the 1989 summer surface, which was harder than the overlying pack and had a marked dust content. The old summer surface is likely to have provided a preferential path for meltwater moving downslope from higher elevations, thereby leading to increased isotopic exchange in the lower part of the 1989/90 snowpack.

\section{DISGUSSION}

The distribution of $\delta^{18} \mathrm{O}$ values in accumulated snow changes as a result of the processes of meltwater percolation and associated isotopic homogenization (Stichler, 1987). However, isotopic homogenization is very slight above the ELA at Austre Okstindbreen in late winter, and the major differences survive in the snowpack for several weeks after the onset of surface melting (Raben and Theakstone, 1994). During the melting phase, the residual snowpack becomes enriched in ${ }^{18} \mathrm{O}$ (Raben and Theakstone, 1998). In summer, the river water discharging from the glacier is relatively depleted of the heavy isotope, with a mean $\delta^{18} \mathrm{O}$ value of around $-13.2 \%$ contrasting with that of glacier ice, $-11.8 \%$ ( Theakstone, 1988).

The relationship between winter $\delta^{18} \mathrm{O}$ values at Austre Okstindbreen and regional temperature changes is affected by local geographical conditions, such as topography and elevation. Differences between the isotopic signal in the accumulated snow at $1350 \mathrm{~m}$ and temperature changes at Susendal are to be expected, because of the differences of altitude and location of the glacier site and the weather station. Nevertheless, variations of 1989/90 winter air temperatures were reflected in the isotopic composition of the snowpack at Austre Okstindbreen. Further work is needed to improve understanding of the relationship between the isotopic record at an alpine glacier and the local climate.

In contrast to the overlying stratigraphy, the variations of $\delta^{18} \mathrm{O}$ values in the firn at $4.1-6.5 \mathrm{~m}$ depth at site 90.1 were slight (Fig. 2), clearly indicating the effects of homogenization on old snow at the melting point. This proceeds rapidly at lower altitudes on the glacier, as witnessed by the changes caused by intense ablation in July at site 90.2 (Fig. 3).

\section{GONGLUSION}

Although the relationship between $\delta^{18} \mathrm{O}$ values in the snowpack and air temperatures during the winter probably was affected by many natural factors, the isotopic variations above the ELA at Austre Okstindbreen provide fundamental information about periodic trends of temperature changes during the period of snow accumulation. Thus, the oxygen isotope record in temperate snow at an alpine glacier can provide an estimate of the approximate trend of local climatic conditions, especially of local temperature variations, although the record is likely to be influenced by more factors than is that at polar glaciers. Isotopic research in the accumulation areas of alpine glaciers can be used as a 
supplementary method for local climatic analysis when no permanent climatic record exists. The isotopic record present in temperate snow and firn changes during the ablation season as a result of meltwater percolation, but the initial variations of $\delta^{18} \mathrm{O}$ values were not entirely eliminated after 1-2 months of ablation at $1350 \mathrm{~m}$ at Austre Okstindbreen in 1990. Isotopic homogenization is pronounced in firn $>4 \mathrm{~m}$ below the previous summer's surface, and the degree of homogenization is likely to increase with time. Where ablation rates are relatively high, changes of isotopic composition and associated homogenization are apparent within a very short period of melting.

\section{ACKNOWLEDGEMENTS}

The work reported here was undertaken whilst He Yuanqing was in receipt of a Postgraduate Studentship of the University of Manchester. It was supported by a grant (GR3/8373) from the U.K. Natural Environment Research Council. The work was also supported by the Chinese Natural Science Foundation (40071023), Cryospheric Changes and their Impact on Resources and Environment in China (KZCX-2-301), and the Innovation Funds (210019) from the Cold and Arid Regions Environmental and Engineering Research Institute, Chinese Academy of Sciences. He Yuanqing received knowledge-innovation support from the Laboratory of Ice Core and Cold Regions Environment. We are grateful to N. Scarle for assistance with the figures. Two anonymous referees made valuable suggestions for improving the paper.

\section{REFERENCES}

He Yuanqing. 1993. Isotopic, ionic and physical studies of snow and firn at the glacier Austre Okstindbreen, Norway, in relation to local climatic variations and to regional atmospheric circulations. (Ph.D. thesis, University of Manchester.)

He Yuanqing and W. H. Theakstone. 1994. Climatic influence on the com- position of snow cover at Austre Okstindbreen, Norway, 1989 and 1990. Ann. Glaciol., 19, 1-6.

Knudsen, N.T. 1991. Mass balance, meltwater discharge and ice velocity at Austre Okstindbreen, Nordland, Norway 1989-90. Manchester, University of Manchester. Department of Geography. (Okstindan Glacier Project Rep. 91.1.)

Naftz, D. L., R. L. Michel and K. A. Miller. 1993. Isotopic indicators of climate in ice cores, Wind River Range, Wyoming. In Swart, P. K., K. C. Lohmann, J. A. McKenzie and S. Savin, eds. Climate change in continental isotopic records. Washington, DC, American Geophysical Union, 55-66. (Geophysical Monograph 78.)

Oerter, H., D. Baker, W. Stichler and W. Rauert. 1985. Isotope studies of ice cores from a temperate Alpine glacier (Vernagtferner, Austria) with respect to the meltwater flow. Ann. Glaciol., 7, 90-93.

Oeschger, H., U. Schotterer, B. Stauffer, W. Haeberli and H. Röthlisberger. 1978. First results from Alpine core drilling projects. Z. Gletscherkd. Glazialgeol., 13(1-2), 1977, 193-208.

Raben, P. and W. H. Theakstone. 1994. Isotopic and ionic changes in a snow cover at different altitudes: observations at Austre Okstindbreen in 1991. Ann. Glaciol., 19, 85-91.

Raben, P. and W. H. Theakstone. 1997. Use of the total input and output of ions to measure meltwater runoff time through a glacier's accumulation area. Ann. Glaciol., 24, 148-151.

Raben, P. and W. H. Theakstone. 1998. Changes of ionic and oxygen isotopic composition of the snowpack at the glacier Austre Okstindbreen, Norway, 1995. Nord. Hydrol., 29 (1), 1-20.

Raben, P., W. H. Theakstone and K. Tørseth. 2000. Relations between winter climate and ionic variations in a seven-meter-deep snowpack at Okstindan, Norway. Arct. Antarct. Alp. Res., 32(2), 189-196.

Ratcliffe, R. A. S. 1990. Review of winter 1989/90 in the Northern Hemisphere. Weather, 45(5), 193-194.

Stichler, W. 1987. Snowcover and snowmelt processes studied by means of environmental isotopes. In Jones, H. G. and W. J. Orville-Thomas, eds. Seasonal snowcovers: physics, chemistry, hydrology. Dordrecht, etc., D. Reidel Publishing Co., 673-726. (NATO ASI Series C: Mathematical and Physical Sciences 211.)

Tangborn, W. 1980. Two models for estimating climate--glacier relationships in the North Cascades, Washington, U.S.A. F. Glaciol., 25(91), 3-21.

Theakstone, W. H. 1988. Temporal variations of isotopic composition of glacier-river water during summer: observations at Austre Okstindbreen, Okstindan, Norway. F. Glaciol., 34(118), 309-317.

Wagenbach, D. 1989. Environmental records in alpine glaciers. In Oeschger, H. and C. C. Langway, Jr, eds. The environmental record in glaciers and ice sheets. Chichester, etc., John Wiley and Sons, 69-83.

Wang Ping. 1985. Applications of isotope geochemistry to research on Chinese glaciers. Ann. Glaciol., 7, 94-99. 